\title{
Orman Meyveli Tarhananın Fonksiyonel Özellikleri
}

\author{
Ömer İstek ${ }^{*}$, Oktay Tomar ${ }^{2}$, Abdullah Çağlar ${ }^{3}$ \\ 1* Afyon Kocatepe Üniversitesi, Mühendislik Fakültesi, Gıda Mühendisliği Bölümü, 03200, Afyonkarahisar, Türkiye (ORCID: 0000-0003-2195-1166), \\ omeristek@gmail.com \\ ${ }^{2}$ Kocaeli Üniversitesi, Ziraat ve Doğa Bilimleri Fakültesi, Arslanbey Kampüsü, 41285, Kocaeli, Türkiye (ORCID: 0000-0001-5761-7157), \\ oktaytomar@hotmail.com \\ ${ }^{3}$ Kocaeli Üniversitesi, Ziraat ve Doğa Bilimleri Fakültesi, Arslanbey Kampüsü, 41285, Kocaeli, Türkiye (ORCID: 0000-0002-9716-8795), \\ abdullahcaglar@hotmail.com
}

(İlk Geliş Tarihi Aralık 2020 ve Kabul Tarihi Ocak 2021)

(DOI: 10.31590/ejosat.848163)

ATIF/REFERENCE: İstek, Ö., Tomar, O. \& Çağlar, A. (2021). Orman Meyveli Tarhananın Fonksiyonel Özellikleri. Avrupa Bilim ve Teknoloji Dergisi, (22), 118-127.

\begin{abstract}
$\ddot{O} z$
Tarhana, Türkiye'de yaygın olarak tüketilen ve buğday unu, yoğurt, çeşitli sebzeler ile baharatların ilavesiyle hazırlanan hamurun fermente edildikten sonra kurutulup öğütülmesi ile elde edilen geleneksel bir fermente üründür. Tarhana içerdiği protein, vitamin ve mineraller nedeni ile her yaş grubu için çok önemli gıdadır. Ayrıca tarhana çeşitli hastalıkların tedavisinde de kullanılmaktadır. Fonksiyonel bir ürün olan tarhananın daha çok faydalı bir ürün olması için bileşimine orman meyveleri ilave edilerek çeşitli hastalıklara karşı potansiyel bir gıda elde edileceği düşünülmektedir. Orman meyveleri (Ahududu, böğürtlen, karadut, kuşburnu ve yaban mersini) antosiyaninler, flavan-3-oller, prosiyanidinler, flavonollar, ellagitanenler ve hidroksisinamatlar dahil olmak üzere polifenollerce zengin bir kaynak olarak bilinmektedir. Orman meyveli tarhananın; kanser, obezite ve kardiyovasküler hastalıklar için biyobelirteçler üzerinde olumlu bir etkiye sahip olduğu da bilinmektedir. Literatürde tarhananın fonksiyonel özelliklerinin beslenme açısından faydalı olduğunu kanıtlayan çalışmalar olmasına rağmen, orman meyvelerinin ilave edilmesiyle ortaya çıkan yeni ürünlerin fonksiyonel özelliklerinin ve etkilerinin daha iyi anlaşılabilmesi için konuyla ilgili daha fazla araştırmaların yapılması gerekmektedir.
\end{abstract}

Anahtar Kelimeler: Tarhana, Orman meyveleri, Beslenme, Antioksidan, Fenolik.

\section{Functional Properties of Forest Fruit Tarhana}

\begin{abstract}
Tarhana is a traditional fermented product that is widely consumed in Turkey and obtained by drying and grinding the dough prepared with the addition of wheat flour, yogurt, various vegetables and spices. Tarhana is a very important food for all age groups due to the proteins, vitamins and minerals it contains. Tarhana is also used in the treatment of various diseases. It is thought that a potential food against various diseases will be obtained by adding forest fruits to its composition so that tarhana, which is a functional product, is more of a useful product. Forest fruits (raspberries, blackberries, blackberries, rosehip and blueberries) are known as a rich source of polyphenols, including anthosyanins, flavan-3-oller, prosiyanidines, flavonols, ellagitanens and hydroxynamates. Forest fruit tarhana; it is also known to have a positive effect on biomarkers for cancer, obesity and cardiovascular diseases. In this review study, increasing functional properties were evaluated due to the effect of forest fruits added to tarhana. Although there are studies in the literature that prove that the functional properties of tarhana are beneficial in terms of nutrition, more studies on the subject need to be done in order to better understand the functional properties and effects of the new products that emerged with the addition of forest fruits.
\end{abstract}

Keywords: Tarhana, Forest fruits, Nutrition, Antioxidants, Phenolic.

\footnotetext{
* Sorumlu Yazar: omeristek@gmail.com
} 


\section{Giriş}

Günümüzde tükettiğimiz gıdalar, sadece açlığı gidermenin ötesinde farklı anlamlar kazanmıştır. Büyümeyi, gelişmeyi desteklemesi, kronik olan hastalıkların risklerini en aza indirgemesi ve sağlıklı bir yaşamın hedeflenmesinde etkili olmaktadır. Bu beklentileri karşılayan gıdalar bilimsel çevrede fonksiyonel gıdalar olarak bilinmektedir. Sayılan tüm bu üstün özellikler göz önüne alındığında geleneksel gidamız olan tarhana fonksiyonel bir gıda olarak tanımlanmaktadır (Çakıroğlu, 2007).

Fermente bir gıda olan tarhana besin değeri ve bileşiminin çeşitliliği bakımından zengin bir gıda maddesidir. Halkın damak zevkine uygun olması ve kurutulduktan sonra kolaylıkla muhafaza edilebilmesi, üretiminin ucuz ve basit olması, kolay hazırlanabilmesi gibi pek çok özelliğinden dolayı değerli bir üründür. $\mathrm{Bu}$ nedenle geleneksel gidamız olan tarhananın besleyicilik değerini artırıcı çalışmalar yapılmaktadır (Ibanoglu \& Ibanoglu, 1999). Tahıl unları, yoğurt ve farklı sebzelerle fermente edilerek hazırlanan tarhana; çocuklar, yaşlılar ve hastalar için oldukça değerli bir gıdadır. Tarhana serbest aminoasitler, organik asitler, vitaminler ve mineraller bakımından da oldukça zengindir (Daglioglu, 2000).

Tarhananın standart bir üretimi bulunmamaktadır. Her ülke ve bölgeye göre temel üretimin aynı olmasının yanı sıra, geleneksel beslenme alışkanlıklarına göre farklı gıda ürünleri, sebze ve meyveler katılarak da üretimi yapılabilmektedir (Erol, 2010).

Orman meyveleri; ormanlık bölgelerde kendiliğinden, hiçbir dış etmen olmadan yetişen yabani meyvelerdir. Bu meyvelerin içeriğindeki mineral, vitamin, fitesteroller ve fenolik bileşiklerinden dolayı güçlü bir biyolojik değere sahip olduğu bilinmektedir (Savikin ve ark., 2014).

Orman meyvelerinin sağlığa faydalı yönlerinde, antioksidan özelliklerinin fazla olması ve meyvelerin fenolik bileşenleri etkili olmaktadır (Koponen ve ark., 2007; Savikin ve ark., 2009; Djordjevic ve ark., 2010). Ahududu (Rubus idaeus), böğürtlen (Rubus fruticosus), karadut (Morus nigra), kuşburnu (Rosa canina) ve yaban mersini (Vaccinium myrtillus) meyvelerinin taze veya işlenmiş ürünlerinin tüketilmesi insan beslenmesinde önemli bir gıda kaynağı olarak bilinmektedir (Garzon ve ark., 2009; Scibisz \& Mitek, 2009; Cote ve ark., 2010). Bu çalışmada tarhanaya ilave edilen orman meyvelerinin etkisiyle arttırılabilecek fonksiyonel özelliklerin beslenme ve insan sağlığ açısından etkileri değerlendirilmiştir.

\section{Tarhananın Beslenme Üzerine Etkileri}

Tarhana; genellikle buğday ürünleri, yoğurt, bazı sebze ve baharatların (kırmızı biber, domates, soğan, nane, tuz vb.) karıştırılarak, laktik asit ve alkol fermantasyonu işlemi sonucunda ortaya çıkan ürünün kurutulup öğütülmesi veya yaş olarak muhafaza edilmesi sonucu tüketilen geleneksel bir gıda ürünü olarak kabul görmektedir (Settanni ve ark., 2011).

Tarhana üretiminde kullanılan domates, dere otu ve biber gibi hammaddeler antioksidan yönünden; tahıllar, bulgur, soğan, fasulye ve nohut gibi hammaddeler ise besinsel lif yönünden zengin oldukları belirlenmiştir. Tarhana üretiminde kullanılan hammaddelerin sabit oranlarda olmaması ve bölgeden bölgeye değişiklik gösterdiği için birden fazla çeşidi bulunmaktadır. Hammadde katkıları sayesinde zengin bir besin kaynağı ve çeşitli hastalıklara faydalı olan tarhana, fonksiyonel bir gida olduğunu kanıtlamıştır (Esimek, 2010).

Tarhananın ana bileşimi olan un, protein kaynağı olarak düşük bir kaliteye sahiptir. Ayrıca esansiyel aminoasitler bakımından treonin, lisin ve metiyonin açısından da oldukça fakirdir. Buna rağmen bakır, demir ve mangan gibi mineral maddeler bakımından zengindir. Tarhananın diğer bir bileşeni olan yoğurt ise aminoasitler bakımından zenginken, mineral maddeler açısından una göre fakir bir içeriğe sahiptir. Karışımda kullanılan un ve yoğurt birbirlerini dengelerken, üretimde kullanılan diğer baharat ve sebzelerde tarhananın besleyicilik ve fonksiyonellik yönünü geliştirmektedir. Ayrıca fermantasyon sonrasında yapısal olarak daha da zengin bir gida maddesi olmaktadır (Baysal, 2007).

Fermente bir ürün olan tarhananın probiyotik özelliği de bulunmaktadır (Baysal, 2007). Bağırsak florasını dengelemek ve vücut bağışıklık sistemini güçlendirmek gibi pek çok özelliği bulunan probiyotik mikroorganizmaların çoğunluğu laktik asit bakterilerinden oluşturmaktadır (Coşkun, 2004). Bundan dolayı tarhana tüketimi sonucu bağırsak sisteminde bulunan patojen bakteriler üzerinde bakterisit etki göstermektedir. Ayrıca organizmada otointoksikasyonunun engellenmesinde büyük rol almaktadır (Erbaş, 2003).

Fonksiyonel bir ürün olan tarhananın besleyici özelliğini arttıran birçok bileşen bulunmaktadır (Tablo 1). Ayrıca tarhananın içeriğindeki tahıllarda fermantasyon işlemi sonrası kobalamin, riboflavin, pantotenik ve folik asit gibi B grubu vitaminlerinde artış olduğu bildirilmiştir (Gökmen \& Çağlar, 2016). Yapılan çalışmalarda tahıllarda bulunan antinutrisyonel faktörlerinde de azalma olduğu saptanmıştır (Aytuna \& Aran, 2002; Dayısoylu ve ark., 2003). Bunun yanı sıra glisemik indeksi düşük gıda grubunda olan tarhana (glisemik indeksi 20) şeker ve obez hastalarının tüketmeleri için önemli bir gıda olarak önerilmektedir (Aksoydan, 2005; Özçelik \& Özdoğan, 2007).

Magala ve ark. (2015) yaptıkları araştırmalarında, $\% 5$ ve $\% 10(\mathrm{w} / \mathrm{w})$ oranlarında portakal ve mandalina diyet lifi katılmasıyla hazırlanan tarhana örneklerinin fermantasyon süresi boyunca etkileri incelenmiştir. Kullanılan diyet lifi preparatlarının buğday ununa kıyasla daha yüksek kül, yağ ve toplam diyet lifi konsantrasyonuna ulaştığ 1 bildirilmiştir. Buğday ununda ise narenciye diyet lifi preparatlarından daha yüksek nem içeriği ve protein konsantrasyonu olduğu ortaya konulmuştur. Portakal ve mandalina diyet lifi preparatları, buğday ununa kıyasla daha yüksek su ve yağ emme kapasitesi, şişme kapasitesi ve en az jelleşme konsantrasyonuna sahip olduğu tespit edilmiştir. Meyveli diyet lifi preparatlarının tarhana tarifine uygulanması, fermantasyon sürecinde $\mathrm{pH}$ 'ın 4.70-5.02 değerlerinden 4.31-4.51 değerlerine hılı bir şekilde düşüş olduğu görülmüştür. Fermantasyon, mevcut mikroorganizmaların metabolik aktivitesinin bir sonucu olarak laktik asit (1.67-2.09 g/kg) ve asetik asit (1.91-2.53 g/kg) üretimi meydana getirmiştir. Ayrıca örneklerin duyusal olarak değerlendirilmesi sonucu, narenciye diyet lifi preparatlarının \%10 oranlarında; tadı, kokuyu, kıvamı ve ekşiliği olumsuz etkilediği saptanmıştır. Bunun yanı sıra en kabul edilebilecek örneğin, \%5 mandalina diyet lifli tarhana olduğu ortaya konulmuştur. Yapılan başka bir çalışmada, karabuğday unu ve kinoa ilavesinin örneklerde protein, fitik asit, toplam fenolik madde ve antioksidan aktivite, magnezyum, demir, çinko, fosfor ve potasyum değerlerinde artış meydana getirdiği bildirilmiştir (Çevik, 2016). 


\begin{tabular}{llll}
\hline Aminoasit & Ortalama İçerik (mg/100g) & Vitamin ve Mineral & Ortalama İçerik (mg/100g) \\
\hline Aspartik Asit & 1440 & Bakır & 450 \\
Glutamik Asit & 5305 & Çinko & 1.8 \\
Histidin & 610 & Demir & 3.6 \\
İzolösin & 654 & Kalsiyum & 109 \\
Lizin & 581 & Magnezyum & 78 \\
Lösin & 1152 & Manganez & 612 \\
Prolin & 6094 & Potasyum & 114 \\
Serin & 1130 & Sodyum & 634 \\
Treonin & 856 & Riboflavin & 0.08 \\
Valin & 851 & Tiyamin & 0.01 \\
\hline
\end{tabular}

Akan (2018) yapmış olduğu çalışmasında, \%1, \%2 ve \%4 oranlarında üzüm çekirdeği ekstraktları tarhanaya ilave edilmiştir. Örneklerin kül, mineral madde, antioksidan kapasite ve toplam fenolik madde değerlerinde kontrol örneğine göre önemli bir artış olduğu saptanmıştır. Ancak örneklerin serbest amino asit ve toplam biyojen amin miktarında azalmalar olduğu görülmüştür. Çalışma değerlendirildiğinde en uygun ekstraktın \%2'lik olduğu belirlenmiştir. Ayrıca farklı bir araştırmada; tarhanaya böğürtlen, karadut ve yaban mersini $(\% 15, \% 25)$ ilave edilmesiyle yaş ve kuru formlardaki tarhana örnekleri elde edilmiştir. En yüksek fenolik madde ve antioksidan kapasite değerlerinin sirasıyla $5346.67 \mathrm{GAE} / \mathrm{g}$ ve $\% 22371.43 \% 25$ böğürtlen katkılı yaş tarhana örneklerinde olduğu tespit edilmiştir (Şemşimoğlu, 2019).

Felek (2019) bal kabağı ve nar kabuğu unları kullanılarak üretilen tarhananın fiziksel, kimyasal ve duyusal parametreleri üzerindeki etkisini araştırmıştır. Bal kabağı unu dondurularak kurutma yönetimi ile elde edilmiş ve $\% 5, \% 10, \% 20,5$ ve $\% 41$ oranlarında tarhana üretiminde un yerine kullanılmıştır. Nar kabukları ise öğütülüp herhangi bir işlem görmeden tarhana üretimine farklı oranlarda (\%5 ve $\% 10)$ un ikamesi olarak ilave

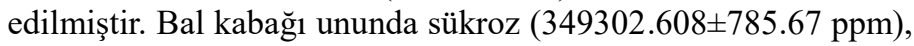
malik asit (17976.556 $\pm 39.25 \mathrm{ppm})$ ve gallik asit $(101.491 \pm 0.491$ ppm) tespit edilen ana bileşenler olurken, nar kabuğu ununda fruktoz (67751.693 $\pm 1069.03 \mathrm{ppm})$, sitrik asit $(7054.569 \pm 153.15$ ppm) ve klorojenik asit (2618.610 \pm 17.43 ppm) baskın ana bileşenler olarak tespit edilmiştir. Bal kabağı ununun oleik ve linoleik asit açısından oldukça zengin oldukları saptanmıştır. Her iki un örneğinin potasyum, magnezyum, fosfor ve kalsiyum yönünden iyi bir kaynak olabilecekleri belirlenmiştir. Bal kabağ ve nar kabuğu unları tarhanaların protein, $\mathrm{pH}$, rutubet, kül, renk, toplam karotenoid ve toplam diyet lif özelliklerini önemli ölçüde etkilemiştir. Toplam karotenoid içeriğinin \%41 bal kabaklı tarhana örneğinde yaklaşık 10 kat arttığ1; \%10 nar kabuklu tarhana örneğinde ise yaklaşık 7 kat arttığı tespit edilmiştir. Bundan dolayı her iki un ingrediyeninin karotenoid açısından fakir gıda yapılarının zenginleştirilmesi amacıyla kullanılabileceği önerilmektedir. Nar kabuğu unu ile elde edilen tarhananın hem diyet lifi hem de antioksidan açısından zenginleştirdiği de belirlenmiştir. Duyusal olarak ise nar kabuğu ve bal kabağı unu ilave tarhana örneklerinin kontrol tarhanasına göre daha çok beğenildikleri bildirilmiştir.

Şensoy (2019) yaptığg araştırmasında, yağı azaltılmış ögütülmüş badem unu (soğuk pres yöntemi) kullanılarak üretilen tarhana örneklerinin beslenme ve duyusal özellikler yönünden daha zengin bir tarhana çeşidinin geliştirilmesi amaçlanmıştır. Farklı oranlarda ( $\% 0$ kontrol, $\% 5, \% 10, \% 15, \% 20, \% 25$ ve $\% 30)$ tarhana hamuruna ilave edilerek örnekler elde edilmiştir. Tarhana numunelerine ait $\mathrm{pH}$, titrasyon asitliği, yağ, kül ve protein sonuçları sırası ile 4.76-5.12, \%0.58-0.79, \%2.19-11.52, \%1.21$1.65, \% 12.28-16.11$ aralığında değiştiği belirlenmiştir. Tarhana örneklerinde yağı azaltılmış badem posasının oranı arttıkça beyazlık (L*) değerlerinin azaldığı; kırmızılık (a*) ve sarılık (b*) değerlerinin ise arttığı tespit edilmiştir. Ayrıca badem posasının toplam fenolik madde miktarı ve antioksidan aktivite değerlerinin arttığ ve sirasılla $1.64-2.36 \mathrm{mg}$ GAE/g ve $0.15-0.43 \mathrm{mg}$ TroloxE/g aralığında olduğu saptanmıştır. Duyusal olarak değerlendirildiğinde, tüm örnekler arasında tarhana üretiminde kullanılabilecek en uygun çeşidin \%30'luk yağı azaltılmış badem posası içeren tarhana çeşidi olduğu ortaya konulmuştur.

Aytunç ve Özsisli (2020) çalışmalarında, belirli bölgelerde tüketilen Maraş tarhanası üretiminde buğday dövmesi yerine, tavlanmış misır ilave edilerek ( $\% 10, \% 20, \% 30, \% 40$ ve $\% 50$ oranlarda) ortaya çıkan tarhana ile Maraş tarhanası arasında önemli farklılıklar olduğu saptanmıştır. Tavlanmış mısır ilavesinin tarhananın hem kimyasal hem de duyusal özelliklerini olumlu yönde etkilediği ortaya konulmuştur. Farklı bir çalışmada ise, tarhanaya \%10 menengiç ilavesinin diğer tüm örneklere göre en yüksek fenolik (5.92 mg GAE/g) ve antioksidan değerlerini (5.39 DPPH mg TE/g) içerdiği bildirmiştir (Kıyak, 2020).

Cındık (2020) çalışmasında, kızılcık tarhanası üretiminde buğday ununun yerine çeşitli tahıl unları (irmik altı unu, karabuğday unu, tam kavuzsuz arpa unu) kullanılarak fermantasyonlu ve fermantasyonsuz koşullarda ayrı ayrı olarak örnekler üretilmiştir. Tam kavuzsuz arpa unu ve irmik altı unu kullanılarak her iki işlem ile üretilen kızılcık tarhanalarının çözünür ve çözünmeyen besinsel lif, fruktan ve makro mineral madde içerikleri önemli düzeyde artış gösterdiği bildirilmiştir. 
İrmik altı unu ve karabuğday unu kullanılarak fermantasyonlu üretilen kızılcık tarhanalarının $\mathrm{Na}, \mathrm{Mg}, \mathrm{K}, \mathrm{S}$ ve Ca makro mineral madde içerikleri fermantasyonsuz üretilenlere göre daha yüksek olduğu ortaya konulmuştur. Bununla birlikte, Çinko (Zn) içeriği, karabuğday unlu fermente kızılcık tarhanası hariç diğer fermente kızılcık tarhanalarında daha düşük olduğu saptanmıştır.

Tomar ve ark. (2020) araştırmalarında, karabuğday ununun farklı oranlarda tarhana yapımına eklenmesi ile yeni fonksiyonel gıda üretilmiştir. Örneklerde karabuğday ilavesinin vizkozite değerlerini azaltmasına rağmen kül ve protein değerlerinde oldukça yüksek bir artış olduğu görülmüştür. En yüksek; protein (\%15.83), kül (\%3.56), DPPH serbest radikal giderme aktivitesi (161.82 mg Teq/g) ve toplam fenolik madde miktarı (14.00 mg GAE/g) olarak \%100 karabuğday unu ile yapılan tarhana örneklerinde olduğu bildirilmiştir. Tarhana üretiminde buğday yerine karabuğday unu katılarak hem besleyicilik yönü arttırılmış hem de çöylak hastalarının tüketmeleri için fonksiyonel bir ürün elde edilmiştir. Buğdayın aksine karabuğday gluten içermemektedir. $\mathrm{Bu}$ yüzden çölyak hastaları için yeni diyet ürünlerinin geliştirilmesinde diğer glutensiz tahıl unları veya nişastalarla birlikte kullanılabilmektedir (Atalay, 2009).

\section{Orman Meyvelerinin İçerdiği Bileşiklerin Önemi}

Orman meyveleri; ormanlık bölgelerde kendiliğinden taze ve doğal olarak yetişen yabani meyveler olarak bilinmektedir. $\mathrm{Bu}$ meyveler hiçbir şekilde gübre veya kimyasal maddeye maruz kalmadan kendiliğinden yetişmektedir. Orman meyveleri grubunda yer alan ahududu, bögürtlen, karadut, kuşburnu ve yaban mersini, kendilerine özgü renk, tat, aroma, yapı ve kokusu ile taze tüketiminin yanı sıra gıda endüstrisinde çok çeşitli kullanım alanları bulunmaktadır. Orman meyveleri içerdikleri bazı fenoller, flavonlar, flavonoidler, pigmentler, lifler ve vitaminler açısından diğer meyve türlerinden konsantrasyon bakımından oldukça yüksek olduğu bilinmektedir (Pehluvan \& Güleryüz, 2004; Anonim, 2018). Seçilen orman meyvelerinin toplam fenolik madde ve toplam antioksidan aktivite değerleri Tablo 2'de verilmiştir.

Ahududu meyveleri yüksek miktarda fenolik bileşikler içermekle beraber antosiyaninde bulundurmaktadır (KrauzeBaranowska ve ark., 2014). Bu bileşenlerden kaynaklı olarak ahududu meyvesinin yüksek oranda antioksidan kapasiteye sahip olduğu belirlenmiştir (Cekic \& Özgen, 2010). Ayrıca ahududu bitkisi antosiyaninlerden, siyanidin-3-(2G-glukozilrutinozit), siyanidin-3-soforozit, siyanidin-3-glukozit, siyanidin-3-rutinozit, pelargonidin-3-glukozit, pelargonidin-3-soforozit, pelargonidin3-(2G-glukozilrutinozit) ve elajitanenlerini içerdiği tespit edilmiştir (Mullen ve ark., 2002). Rubus idaeus meyvesinin sirinjik asit, ellajik asit, kafeik asit, ferulik asit, pirogallol, kersetin, kateşin, klorojenik asit, $\alpha$-tokoferol, p-hidroksibenzoik asit, p-kumarik asit, gallik asit, askorbik asit ve vanilin olarak antioksidan kapasitede çok etkili olduğu bildirilmiştir (Gülcin ve ark., 2011). Ayrıca bu bileşenlerden en çok sanguin H-6 ve lambertianin C'nin damarlarda vazodilatör etkiye sahip oldukları saptanmıştır (Mullen ve ark., 2002).

Böğürtlen; fenoller, antosiyaninler, flavonlar, flavonoidler, ellagitannin, pigmentler, vitamin ve liflerden dolayı diğer meyve türlerinden konsantrasyonları açısından oldukça yüksek olduğu saptanmıştır (Sarıburun, 2009). İçerdiği temel antosiyaninlerden başta siyanidin-3-glukozit olmak üzere siyanidin-3-rutinosit, siyanidin-3-ksilozil ve malik asit esterler bulunmaktadır (Siriwoharn \& Wrolstad, 2004; Fan-Chiang \& Wrolstad, 2005). Sinamik asitler olan; para-kumarik, kafeik, ferulik, klorojenik ve kuinik asitler ve hidroksisinnamik asitlerin glukoz esteri ise bögürtlende oldukça fazla içerdiği bilinmektedir (Schuster \& Herrmann, 1985). Ayrıca böğürtlen meyvelerinde temel ellagitannin ise Sanguiin H-6 olduğunu göstermektedir (Clifford \& Scalbert, 2000). Orman meyvesi olan böğürtlen içerdiği başlıca fenolik bileşenler olan flavonoller, kuersetin, kamferol glikozitleri, epikateşin ve kateşin açısından zengin olduğu için antioksidan konsantrasyonu da oldukça yüksektir (Arts ve ark., 2000).

Karadut fenolik içeriğinde; kateşin, klorojenik asit, pkumarik asit, rutin ve kuersetin gibi bileşenleri yapısında içermektedir. Karadutun ekolojik koşulları, genetik faktörleri, ekim alanı ve şartları fenolik bileşiğin içeriğinin değişmesinde etkili olmaktadır. Karadut içeriğindeki fenolik bileşenlerin büyük çoğunluğu, lezzetin oluşmasında önemli bir faktördür (Yalg1Uygur, 2015). Karadut meyvesinde; antioksidan etkiyi yapısında bulundurduğu fenolik bileşiklerin serbest radikalleri yok etmesinden dolayı peroksidasyon oluşturmaktadır. Ayrıca antioksidan aktivitelerin farklılık göstermesi nedeni fenolik bileşiklerin yapısından kaynaklanmaktadır. Polifenoller olan polimeriklerin, basit monomeriklere göre daha iyi bir antioksidan aktivite gösterdiği belirlenmiştir (Bacanlı ve ark., 2015). Karadut; fenolik madde, antosiyanin, antioksidan ve potasyum açısından önemli bir orman meyvesi olarak bilinmektedir. Ayrıca antibakteriyel ve antifungal özellikleri bulunmaktadır (Erbay, 2011).

Tablo 2. Bazı Orman Meyvelerinin Toplam Fenolik Madde ve Antioksidan Aktivite Değerleri

\begin{tabular}{llll}
\hline Orman Meyveleri & $\begin{array}{l}\text { Toplam Fenolik Madde } \\
\text { (mg GAE/100g) }\end{array}$ & $\begin{array}{l}\text { Toplam Antioksidan Aktivite } \\
(\boldsymbol{\mu m o l ~ T E / g )}\end{array}$ & Kaynak \\
\hline Ahududu (Rubus idaeus) & 383.0 & 39.5 & (Mihailović ve ark., 2019) \\
Böğürtlen (Rubus fruticosus) & 1541 & 102 & (Siriwoharn ve ark., 2004) \\
Karadut (Morus nigra) & $1766.00-3488.00$ & $7.3-16.9$ & (Özgen ve ark., 2009) \\
Yaban mersini (Vaccinium myrtillus) & 819.12 & 56.65 & (Bunea ve ark., 2011) \\
Kuşburnu (Rosa canina) & $104.92-141.57$ & $84.32-138.81$ & (Dolek ve ark., 2018) \\
\hline
\end{tabular}


Orman meyvelerinden olan kuşburnu, C vitaminini diğer bitkilere göre en fazla içeren meyvedir. Ayrıca içeriğinde $A, B_{1}$, $\mathrm{B}_{2}, \mathrm{C}, \mathrm{E}, \mathrm{P}$ ve $\mathrm{K}$ vitaminleri bulunmaktadır. Mineral madde açısından da iyi bir fosfor ve potasyum kaynağıdır (Öz ve ark., 2018). Kuşburnu fenolik bileşiklerce de oldukça zengindir. Hidroksisinamik asit, kateşin, quercetin, kamferol kuşburnunda bulunan önemli fenolik bileşiklerdir (Yi ve ark., 2007). Ayrıca kuşburnunun bileşiminde çeşitli organik asitlerde (malik, sitrik ve asetik asit) bulunmaktadır (Çağlar \& Demirci, 2019).

Yaban mersini; özellikle fenolik asitler (ellajik asit, benzoik asit ve hidoksinnamik asit), fenolik bileşenler ve flavonoidler (flavonol, flavan-3-ol, proantosiyanin ve antosiyanin) açısından zengin bir orman meyvesidir (Vvedenskaya ve ark., 2004). Yüksek antioksidan ve antosiyanin konsantrasyonu ve diğer fenolik bileşenleri de içermektedir. Bu aktiviteleri yaban mersinin içeriğindeki, fenolik bileşikler olan kateşin, klorojenik asit, kuersetin, kamferol, mirisetin, prosiyanidin, epikateşin ve resveratrol tarafından sağlamaktadır. Ayrıca zengin bir $\mathrm{C}$ vitamini kaynağı olarak da bilinmektedir (Giovanelli \& Buratti, 2009).

\section{Orman Meyveli Tarhananın Fonksiyonel Özellikleri}

Tarhana içeriğinin zengin olmasından dolayı protein ve vitamin bakımında oldukça iyi bir gıdadır. Bundan dolayı yaşlıların ve çocukların beslenmesinde tercih edilmektedir (Ibanoglu ve ark., 1999). Sütten kesilen bebeklerin sağlıklı bir şekilde beslenmesinde tarhana büyük bir rol oynamaktadır (Daglioglu ve ark., 2002). Tarhana aynı zamanda iştah açıcı ve bağırsak florasının düzenleyici bir özelliği de bulunmaktadır (Göçmen ve ark., 2003). Ayrıca besin değeri yüksek ve sindirilebilirliği iyi olan bir gıda maddesidir (Certel \& Ertugay, 1997).

Ahududu (Rubus idaeus) meyvelerinin tıbbi amaçlarla kullanıldığı belirtilmektedir. Ayrıca Rubus idaeus meyvesi biyoaktif fenolik antioksidanların önemli kaynağı olarak bilinmektedir. Rubus idaeus meyvelerinin yüksek orandaki antosiyanin içeriğinden kaynaklı güçlü antienflamatuvar ve antioksidan etkilere neden olduğu ve akciğer, kolon, mide ve meme tümör hücrelerini \%20-54 aralığında azalttığı da saptanmıştır (Bowen-Forbes ve ark., 2010).

Hummer (2010) yaptığı çalışmada, ahududu meyvelerinin içermiş olduğu bileşikleri, oksijen radikallerini süpürmek için güçlü bir antioksidan kapasiteye sahip olduğu ve in-vitro çalışmalarda oksidasyonun, patojenik bakterilerin ve bazı kanser hücre hatlarının büyümesini inhibe edici özelliklere sahip olduğu bildirmiştir.

Nowak ve ark. (2017) araştırmalarında, ahududu meyvesi içeriğinde bulunan ellagitanninler insan kolon adenokarsinom hücre hattı Caco-2'ye karşı olan biyoaktif aktiviteleri incelenmiştir. Rubus idaeus bileşimindeki ellagitanninlerin kolon kanser hücrelerinin gelişmesini engellediği ve kemopreventif aktiviteye sahip olduğu tespit edilmiştir. Gıda maddelerinin sağlık yararlarını artırmak için doğal bir gıda katkı maddesi olarak kullanılabileceği önerilmektedir.

Böğürtlen (Rubus fruticosus) meyvesi; insan sağlığ1 ve zindeliği için gerekli olan diyet lifi, antioksidanlar, mineraller ve vitaminlerce oldukça zengin olduğu belirlenmiştir. Bu bileşikler insanlar1; özellikle kolon kanseri, nörolojik, yaşlanma ve iltihaplanma gibi hastalıklardan korumaktadır. İçeriğindeki folik ve askorbik asitin bulunması nedeniyle diabetes mellitus (şeker hastalığı) gibi yaşamımızı etkileyen hastalıkların engellenmesinde büyük önem arz etmektedir (Zia-Ul-Haq ve ark., 2014).

Stoner ve ark. (2006) araştırmalarında, böğürtlenin antikanser aktivitesini kontrol etmek için, AIN-76 olan sıçanların diyetine \%5-10 aralığında farklı konsantrasyonlarda böğürtlen tozu karıştırılmıştır. Sıçanlara özofagus kanserojen Nnitrosometilbenzilamin (NMBA) ile verilmiştir. NMBA tedavi öncesinde ve 25 . hafta sonrası yapilan kontrolleri karşılaştırıldığında, tüm bögürtlen türleri NMBA ile tedavi edilen hayvanlarda özofagus tümörlerinin (papillomlar) \%24-56 oranında inhibisyonuna neden olduğu bildirilmiştir. İnhibisyonun, özofagus DNA'sında NMBA ile indüklenen O-6-metilguanin oluşumundaki azalma ile bağlantılı olduğu tespit edilmiştir. $\mathrm{Bu}$, azalmanın DNA hasarına yol açan NMBA metabolizmasının meyvelerden etkilendiğini ve bu nedenle sıçanlarda özofagus kanserinin önlenmesinde etkili olduğu ortaya konulmuştur.

Sangiovanni ve ark. (2013) çalışmalarında, böğürtlen meyvesinin içeriğinde fazlaca bulunan ellagitannin ile zenginleştirilmiş ekstraktların (ZE'ler) mide intihaplarına karşı etkileri araştırılmıştır. İn vitro ve in vivo modellerinde mide ihtihaplarının kontrolü için $R$. fruticossus ZE'ler, TNFa ile indüklenen NF- $\kappa \mathrm{B}$ tarafindan yönlendirilen transkripsiyonu (IC50: $0.67-1.73 \mathrm{mg} / \mathrm{mL}$ ) ve IL-8 sekresyonunu (IC50: $0.7-4$ $\mathrm{mg} / \mathrm{mL}$ ) inhibe ettiği tespit edilmiştir. Başlıca ZE'ler ise sanguiin H-6 ve lambertianin C olarak belirlenmiş olup, ülser indeksi ile test edildiğinde $\% 88$ oranlarından $\% 75$ ' e düşürdüğü görülmüştür. Elde edilen sonuçlar ZE'lerin mide iltihaplarına karşı koruyucu etkisinin olduğu bildirilmiştir.

Orman meyvelerinden olan karadutun (Morus nigra) fenolik bileşenleri çeşitli hastalıkların (antioksidan, antienflamatuvar, antiapopotik, antibakteriyel, antiallodinik, antianjiyogenez, antiöstrojen, mutajen, enzim düzenleme, diş eti, kanser ve kalp damar rahatsızlıkları) riskini azalttığı bildirilmektedir (Iglesia ve ark., 2010). Karadut modern tıpta tek olarak şurup sanayisinde kullanılmaktadır. Ağız ve boğaz hastalıklarına, özellikle de bebeklerde pamukçuk oluşmasına engelleyici bir etkisi olduğu bilinmektedir. Ayrıca karadut şurubu gargara olarakta tercih edilmektedir. Karadut meyvesinin iştah açıcı etkinliği de bulunmaktadır (Meral \& Doğan, 2012).

Helicobacter pylori, mide karsinojenez problemlerini harekete geçirmede en iyi bilinen faktörlerden birisi olarak bilinmektedir (Nishizawa \& Suzuki, 2015). Huang ve ark. (2011) çalışmalarında, karadut meyvelerinden antosiyanin açısından zengin meyvelerin mide karsinomu oluşumunu durdurmak için kullanılabileceği bildirilmiştir.

Mazimba ve ark. (2011) karadutun toprak üstü kısımlarından izole bileşenlerin (oxyresveratrol, moracinM, cyclomorusin, morusin, kuwanon $\mathrm{C}$ ve bir kuwanon $\mathrm{C}$ türevi) antibakteriyel etkileri araştırılmıştır. Farklı patojen bakterilere $(S$. aureus, $B$. subtilis, Micrococcus flavus, S. faecalis, Salmonella abony ve $P$. aeruginosa) antibakteriyel etki gösterdiği tespit edilmiştir. En fazla antibakteriyel etkiyi ise $B$. subtilis'e karş1 (MİK değeri 3.91 $\mathrm{g} / \mathrm{mL}$ ) olduğu saptanmıştır. Ayrıca karadutun, dört farklı bakteri türü olan Escherichia coli, Bacillus subtilis, Staphylococcus aureus ve Streptococcus mutans'a karşı da aktif ve güçlü bir aktivite gösterdiği bildirilmiştir (Tahir ve ark., 2017).

Ahmed ve ark. (2016) karadutunun taze ve kurutulmuş meyvelerin antikanser etkisi araştırılmıştır. Morus nigra 
meyvelerinin MCF-7 hücrelerinin aktivitesini yavaşlattığını ve enfekte hücrelerin hücre ölümüne neden olduğunu ve sitoplazmik zarlarda morfolojik değişikliklere neden olduğu bildirilmiştir. DNA'yı tek sarmala dönüştürerek hücredeki mitotik aktivitelerin seviyesini düşürerek iyi farmakolojik fonksiyon sağladığı tespit edilmiştir.

Yaban mersini (Vaccinium myrtillus) içerdiği fenolik bileşenler; mide ülseri ve idrar yolu enfeksiyonu gibi hastalıklara karşı engelleyici ve koruyucu etkisi olduğu bilinmektedir (Zhang ve ark., 2005). Koruyucu etki mekanizması, bakteri hücresinin vücutta doku ve yüzeye tutunmalarını fenolik bileşenlerin engellediği belirlenmiştir. Ayrıca içeriğindeki polifenollerinin kardiyovasküler hastalıklara yakalanma riskini düşürdüğü ve diyabet hastalarında kandaki şeker oranını dengelediği tespit edilmiştir (Ruel ve ark., 2008; Wilson ve ark., 2008). Yaban mersini fenolik bileşenlerinin antibakteriyel, antimutajenik, antikarsinojenik ve antioksidan aktivitelerinin olduğu belirlenmiştir (Caillet ve ark., 2012; Vu ve ark., 2012).

Göz yorgunluğu, ağrı, kuru göz hissi, aşırı gözyaşı, bulanık görme, glokom, katarakt ve özellikle günlük işlerde daha fazla göz yorgunluğu gerektiren kişilerde görme kalitesini bozabilecek en yaygın değişiklikler olarak bilinmektedir (Ozawa ve ark., 2015). Riva ve ark. (2017), standardize edilmiş bir $V$. myrtillus ekstresinin biyoyararlılığını ve kuru göz semptomlarını hafifletme kabiliyetini incelenmiş olup, kuru göz semptomlarından muzdarip deneklerde gözyaşı salgılanmasını iyileştirebileceği sonucuna ulaşılmıştır. Diğer çalışmalarda ise, V. myrtillus özlerinin yararlı oküler etkilerini, yani gece görüşünde iyileşme, katarakt ve glokomu önleme etkilerinin bulunduğu ortaya konulmuştur (Head, 2001; Canter \& Ernst, 2004).

Sun ve ark. (2002) yaptıkları çalışmalarda yaban mersinin ekstraktları ile karaciğer kanserine neden olan hücrelerinin gelişmesini engellediği tespit edilmiştir. İçerdiği antosiyaninlerinin insanlarda LDL oksidasyonunu azaltmaktadır. Ayrıca hayvanlarda da toplam kolesterolü düşürdüğü bildirilmiştir (Leahy ve ark., 2002).

Qin ve ark. (2009) yaptıkları bir insan çalışmasında, yaban mersini (Vaccinium myrtillus) ve siyah frenk üzümünden (Ribes nigram) elde edilen karışı antosiyaninler ile 12 hafta boyunca orta yaşlı dislipidemik 60 kişilik Çinli bir denek grubu için bir özüt (320 mg/gün) olarak verilmiştir. Elde edilen sonuçlar, düşük yoğunluklu lipoprotein (LDL) kolesterolde yaklaş1k \%14 ortalama düşüş olduğu ve yüksek yoğunluklu lipoprotein (HDL) kolesterolde yaklaşık \%14 ortalama artış olduğu tespit edilmiştir.

Toivanen ve ark. (2011), V. myrtillus'tan üretilen meyve sularının, $10 \mathrm{mg} / \mathrm{mL}$ konsantrasyonda $\% 63$ büyüme inhibisyonu ile Neisseria meningitidis'in neden olduğu pnömokok enfeksiyonlarına karşı potansiyel gösterdiği bildirilmiştir. Benzer şekilde Huttunen ve ark. (2011), çoğunlukla şekerlerden ve bazı miktarlarda küçük boyutlu fenoliklerden oluşan yaban mersini meyve suyu fraksiyonlarının Streptococcus pneumoniae'nin insan bronşiyal hücrelerine bağlanmasına karşı inhibe edici aktivitesini incelenmiştir. Antimikrobiyal testlerinde kullanılan en yüksek konsantrasyonun ( $\sim 86 \mathrm{mg} / \mathrm{g})$ olduğu sonucuna ulaşılmış olup, son derece etkili olduğu saptanmıştır. Ayrıca S. pneumonia'nın gelişmesi, $V$. myrtillus özütü ile tamamen inhibe edilmiştir. Yapılan bazı çalışmalar sonucunda yaban mersini içerisindeki fenolik bileşikler ve organik asitler bileşimi nedeniyle patojenik bakterilere karşı koruyabileceğini öne sürülmektedir (PuupponenPimiä ve ark., 2008).
$\mathrm{Xu}$ ve ark. (2018) fenolik bileşikler bakımından zengin olan V. myrtillus gibi meyvelerin tüketiminin, genç erişkinlerde yemek sonrası glisemik ve insülin tepkilerini azaltabildiğini, yemekten 30 dakika sonra en fazla insülin düşürücü etkiye sahip yaban mersini meyvelerinin olduğunu saptanmıştır. Bu etki yemek sonrası erken dönem boyunca devam ettiği ve tüketilen fenolik bileşik miktarı ile ilişkili olduğu belirlenmiştir. Ayrıca farklı çalışmalarda, $V$. myrtillus meyvelerinden polifenol bakımından zengin ekstrelerin $\alpha$-glukozidaz ve amiloglukozidaz aktiviteleri üzerinde inhibe edici etkiler bildirdiği ortaya konulmuştur. Özellikle fenolik asitle zenginleştirilmiş fraksiyonlar, tip 2 diyabeti kontrol etmenin en etkili yollarından biri olarak kabul edilen in vitro $\alpha$-glukosidazı inhibe edebildiği bildirilmiştir (De Mello ve ark., 2017; Pires ve ark., 2020).

Sezer ve ark. (2019), V. myrtillus özlerinde bulunan en bol antosiyanin olmayan polifenoller olan quercetin ve kaempferolün güçlü sitotoksik, antioksidan ve apoptotik etkiler gösterdiğini bulmuşlardır. $V$. myrtillus antosiyaninleri ayrıca tümör baskılayıcı genleri yukarı düzenleme, kanser hücrelerinde apoptozu indükleme, genomik DNA bütünlüğünü onarma, koruma, nöronal ve bilişsel beyin fonksiyonunu iyileştirme yeteneklerinin de olduğu bildirilmiştir.

Kuşburnunun (Rosa canina) beslenme ve tıbbi değeri konusundaki çalışmalar çok eski yıllara kadar dayanmaktadır. Hipokrat zamanından iltihaplara karsı, Orta çă̆ ve sonrası dönemlerde diş eti kanamalarına, böbrek meme safra taşlarına, tenyaya, yılancık hastalığına ve kan tükürmelere karsı tedavi etmek amacıyla kullanılmıştır. Ayrıca şeker hastalıklarına, yan ağrılarına ve ishale karsı kullanıldığı da bilinmektedir. Ülkemizde ise hemoroide, raşitizme ve romatizmaya karsı tedavi edici etkilerinden dolayı kullanılmaktadır (Özarda, 2009).

Kanın temizlenmesinde, bağırsakların yumuşaması ve kurt düşrücü özelliğiyle bilinen Rosa canina, C vitamini zeginliğinden dolayı vücudun gelişmesine de önemli katkıları bulunmaktadır. Ayrıca vücutta bağ dokusunun sağlam ve sıkı olmasını sağlayarak soğuk algınlığı, nezle, grip ve diğer ateşli hastalıklara karsı vücut direncini arttırmaktadır. Vitamin ve fenolik bileşenlerinden dolayı antioksidan etki göstererek kanser riskini önlemekte, damar cidarının sağlam olmasını sağlayarak kanamaların önlenmesinde etkili olmaktadır. (Özarda, 2009).

Niominya ve ark. (2008) Rosa canina'nın meyvelerinden (50 $\mathrm{mg} / \mathrm{kg} / \mathrm{gün}$ ) ve tohumlarından (12.5 ve $25 \mathrm{mg} / \mathrm{kg} / \mathrm{gün}$ ) elde edilen $\% 80$ sulu aseton özütlerinin, plazma trigliserit (PT) ve serbest yă asidi (SYA) seviyelerini önemli ölçüde düşürdüğü tespit edilmiştir. Farelerde 14 günlük tedavi sonrasında, bu ekstraktın ana biyoaktif bileşiği, uygulamasının karaciğer PT seviyelerini önemli ölçüde düşürdüğü saptanmıştır. Bunun yanı sıra SYA seviyelerinde de düşürme eğilimi saptanmıştır. Ancak önemli ölçüde azaltmayan trans-tilirosidinlerin olduğu görülmüştür. Ayrıca trans-tilirosidin, tek oral uygulamadan 24 saat sonra karaciğer dokusunda peroksizom proliferatör ile aktive olan reseptör $\alpha$ (PPAR- $\alpha)$ mRNA düzeylerinin ekspresyonunu arttırdığı bildirilmiştir. Bu sonuçlara göre, Rosa canina'nın antilipidemik etkisinin lipid metabolizmasını geliştirme kapasitesine dayandırılabileceği ortaya konulmuştur.

Kuşburnunun obezitenin önlenmesi için potansiyel faydalarına odaklanan Ninomiya ve ark. (2008), Rosa canina'da bulunan bir glikozidik flavonoid olan trans-tiliroside'nin (kaempferol 3-O- (600-p-kumaroil) - $\beta$-glukozit) anti-obezite özellikleri araştırılmıştır. Sıçan modellerine tek başına transtilirositin kuşburnu ekstrelerinin uygulanması, aşırı kilo ve 
karaciğer yağ birikiminde bir azalmaya yol açtığı tespit edilmiştir. Ayrıca, peroksizom proliferatör ile aktive edilen reseptör $\alpha$ $($ PPAR $\alpha)$ aşırı eksprese edildiğinden, lipid metabolizmasının trans-tilirosid uygulamasından sonra arttığı saptanmıştır. PPAR $\alpha$, aktivasyonu yağ asitleri oksidasyonunu desteklediğinden ve PPAR $\alpha$ agonistlerinin kullanımı obezite ile ilişkili yan etkileri iyileştirdiğinden lipid seviyelerini düşürdüğü bildirilmiştir (Grygiel-Górniak, 2014).

Jiménez ve ark. (2016) çalışmalarında kuşburnu ekstraktının, kolon kanseri hücre hattında (Caco-2) farklı Rosa canina ekstraktlarının anti-kanser özellikleri incelenmiştir. Hem düşük hem de yüksek konsantrasyonlarda, hücre proliferasyonuna inhibe edici etki gösterdiği tespit edilmiştir.

\section{Sonuç}

Tarhana, hammadde katkıları sayesinde zengin bir gıda kaynağı ve çeşitli hastalıklara faydalı olduğu farklı çalışmalarla belirlenmiştir. Fonksiyonel bir ürün olan tarhanaya orman meyvelerinin ilavesiyle ürünlerin mevcut faydalarının yanı sıra daha farklı beslenmeye ve insan sağlığa yönelik yararlarının arttırılabileceği öngörülmektedir.

Orman meyveleri olarak bilinen ahududu (Rubus idaeus), böğürtlen (Rubus fruticosus), karadut (Morus nigra), kuşburnu (Rosa canina) ve yaban mersini (Vaccinium myrtillus) sağlık açısından önemli bir faktör olan fenol, flavon ve flavonoidleri yüksek oranda içermektedir. Fonksiyonel bir gida olarak orman meyveli tarhananın antioksidan kapasitesi ve fenolik bileşenlerinin oldukça yüksek olacağı aşikardır. Bu fonksiyonel gidanın antidiyabetik, antioksidan, antikanserojen, antiobezite ve antibakteriyel rolleri nedeniyle insan sağlığında diğer gidalar ile karşılaştırılmayacak kadar faydalı bir gıda olacakları görülmektedir.

İnsanların diyet sağlığına ve sağlıklı gıdaların tüketilmesine olan bilinci gün geçtikçe artmaktadır. Tarhana ve orman meyvelerinin insan sağlığı ve beslenmesi açısından oldukça değerli ürünler olduğu bilinmektedir. Özellikle orman meyveleriyle ilgili ülkemizde yapılan sınırlı sayıda çalışma bulunmaktadır. Gelecek yıllarda yapılacak çalışmalarla orman meyvelerinin diğer çeşitlerinin biyoaktif bileşiklerinin detaylandırılmasıyla ülke ekonomisine ve literatüre önemli katkılar sağlanmış olacaktır.

\section{Kaynakça}

Ahmed, A., Ali, M., El-Kholie, E., El-Garawani, I., \& Sherif, N. (2016). Anticancer activity of Morus nigra on human breast cancer cell line (MCF-7): The role of fresh and dry fruit extracts, Journal of Bioscience and Applied Research, 2, 352361.

Akan, S. (2018). Farklı Oranlarda Üzüm Çekirdeği Ekstraktı ile Zenginleştirilmiş Tarhana Örneklerinin Fermantasyon ve Depolama Periyodu Boyunca Bazı Kimyasal Özelliklerinin Belirlenmesi. Yüksek Lisans Tezi. Ege Üniversitesi Fen Bilimleri Enstitüsü, İzmir.

Aksoydan, E. (2005). Yaşlılık ve Beslenme. Ankara: Burgaz Matbaas1.
Anonim
(2018).
Orman
Meyveleri. https://www.orman.gen.tr/orman-meyveleri.html. Erişim: 04.09.2019.

Arts, I. C., Van De Putte, B., \& Hollman, P. C. (2000). Catechin contents of foods commonly consumed in The Netherlands. 1. Fruits, Vegetables, Staple Foods, and Processed Foods. Journal of Agricultural and Food Chemistry, 48(5), 17461751.

Atalay, M. H. (2009). Karabuğday (Fagopyrum esculentum) Ögütme Ürünlerinin Ekmek Üretiminde Kullanılma İmkanları. Yüksek Lisans Tezi. Selçuk Üniversitesi, Fen Bilimleri Enstitüsü, Konya.

Aytuna, H., \& Aran, N. (2002). Tahıl ürünlerinde fermantasyon uygulamaları ve besin değerleri üzerine etkileri. Hububat Ürünleri Teknolojisi Kongre ve Sergisi (ss. 365-373). Gaziantep, 3-4 Ekim 2002.

Aytunç, R., \& Özsisli, B. (2020). Determination of some properties of the traditional maras tarhana produced by tempered corn addition. Turkish Journal of Agriculture-Food Science and Technology, 8(5), 1067-1073.

Bacanlı, M., Taner, G., Başaran, A. A., \& Başaran, N. (2015). Bitkisel kaynaklı fenolik yapıdaki bileşikler ve sağlığa yararlı etkileri. Türkiye Klinikleri, 4(1), 9-16.

Baysal, A. (2007). Beslenme. Hatiboğlu Yayınları: 93. Ders Kitabı Dizisi: 26. 11. Baskı. Ankara: Alp Ofset Matbaacılık Ltd. Şti.

Bowen-Forbes, C. S., Zhang, Y., \& Nair, M. G., (2010). Anthocyanin content, antioxidant, anti-inflammatory and anticancer properties of blackberry and raspberry fruits. Journal of Food Composition and Analysis, 23, 554-560.

Bunea, A., Rugina, O. D., Pintea, A. M., Sconţa, Z., Bunea, C. I., \& Socaciu, C. (2011). Comparative polyphenolic content and antioxidant activities of some wild and cultivated blueberries from Romania. Notulae Botanicae Horti Agrobotanici ClujNapoca, 39(2), 70-76.

Caillet, S., Cote, J., Sylvain, J. F., \& Lacroix, M. (2012). Antimicrobial effects of fractions from cranberry products on the growth of seven pathogenic bacteria. Food Control, 23(2), 419-428.

Canter, P. H., \& Ernst, E. (2004). Anthocyanosides of Vaccinium myrtillus (bilberry) for night vision-a systematic review of placebo-controlled trials. Survey of Ophthalmology, 49(1), $38-50$.

Cekic, C., \& Özgen, M. (2010). Comparison of antioxidant capacity and phytochemical properties of wild and cultivated red raspberries (Rubus idaeus L.). Journal of Food Composition and Analysis, 23, 540-544.

Certel, M., \& Ertugay, M. F. (1997). Moisture adsorption isotherms of Tarhana. Turkish Journal of Agriculture and Forestry, 21(5), 475-479.

Cındık, B. (2020). Kızılcık Tarhanalarının Çirişlenme ve Bazı Besinsel Özellikleri Üzerine Fermantasyonun Etkisi. Yüksek Lisans Tezi. Bolu Abant İzzet Baysal Üniversitesi, Lisansüstü Eğitim Enstitüsü, Bolu.

Clifford, M. N., \& Scalbert, A. (2000). Ellagitannins-occurrence in food, bioavailability and cancer prevention. Journal of the Science of Food and Agriculture, 80(7), 1118-1125.

Coşkun, T. (2004). Pre-pro- ve sinbiyotikler. Katkı Pediatri Dergisi, 26, 151-197. 
Coşkun, F. (2014). Tarhana ve beslenme yönünden önemi. Gıda ve Yem Bilimi Teknolojisi Dergisi, 3, 46-49.

Cote, J., Caillet, S., Doyon, G., Sylvain, J. F., \& Lacroix, M. (2010). Analyzing cranberry bioactive compounds. Critical Reviews in Food Science and Nutrition, 50, 872-888.

Çağlar, M., \& Demirci, M. (2017). Üzümsü meyvelerde bulunan fenolik bileşikler ve beslenmedeki önemi. Avrupa Bilim ve Teknoloji Dergisi, 7(11), 18-26.

Çakıroğlu, F. P. (2007). Geleneksel tarhananın modern yolculuğu. 38. ICANAS Uluslararası Asya ve Kuzey Afrika Çalışmaları Kongresi (ss. 349-360). Ankara, 10-15 Eylül 2007.

Çevik, A. (2016). Tarhananın Besinsel Zenginleştirilmesinde Kinoa, Karabuğday ve Lüpen Unlarının Kullanımı. Yüksek Lisans Tezi. Necmettin Erbakan Üniversitesi, Fen Bilimleri Enstitüsü, Konya.

Daglioglu, O. (2000). Tarhana as a traditional Turkish fermented cereal food, its recipe, production and composition. Nahrung, 44(2), 85-88.

Daglioglu, O., Arici, M., Konyalı, M., \& Gumus, T. (2002). Effects of tarhana fermentation and drying methods on the fate of Escherichia coli 0157:H7 and Staphylococcus aureus. European Food Research and Technology, 215(6), 515-519.

Dayısoylu, K. S., Gezginç, Y., \& İnanç, A. L. (2003). Kahramanmaraş tarhanasına besin fonksiyonelliği açısından bir bakış. 3. Gıda Mühendisliği Kongresi (ss. 511-523), Ankara, 2-4 Ekim 2003.

De Mello, V. D., Lankinen, M. A., Lindström, J., PuupponenPimiä, R., Laaksonen, D. E., Pihlajamäki, J., ... \& Hanhineva, K. (2017). Fasting serum hippuric acid is elevated after bilberry (Vaccinium myrtillus) consumption and associates with improvement of fasting glucose levels and insulin secretion in persons at high risk of developing type 2 diabetes. Molecular Nutrition \& Food Research, 61(9), 1700019.

Djordjevic, B., Savikin, K., Zdunic, G., Jankovic, T., Vulic, T., Oparnica, C., \& Radivojevic, D. (2010). Biochemical properties of red currant varieties in relation to storage. Plant Foods for Human Nutrition, 65, 326-332.

Dolek, U., Gunes, M., Genc, N., \& Elmastas, M. (2018). Total phenolic compound and antioxidant activity changes in rosehip (Rosa sp.) during ripening. Journal of Agricultural Science and Technology, 20(4), 817-828.

Erbaş, M. (2003). Yaş Tarhananın Üretim ve Farklı Saklama Koşullarında Bileşimindeki Değişmeler. Doktora Tezi. Akdeniz Üniversitesi, Fen Bilimleri Enstitüsü, Antalya.

Erbay, B. (2011). Karadut Antosiyaninlerinin Isıl ve Depolama Stabilitesi. Doktora Tezi. Süleyman Demirel Üniversitesi, Fen Bilimleri Enstitüsü, Isparta.

Erol, N. I. (2010). Keçiboynuzlu Tarhana Üzerine Bir Araştırma. Yüksek Lisans Tezi. Afyon Kocatepe Üniversitesi, Fen Bilimleri Enstitüsü, Afyonkarahisar.

Esimek, H. (2010). Tarhananın Besinsel Lif İçeriği ve Antioksidatif Özelliklerinin Belirlenmesi. Yüksek Lisans Tezi. İnönü Üniversitesi, Fen Bilimleri Enstitüsü, Malatya.
Fan-Chiang, H. J., \& Wrolstad, R. E. (2005). Anthocyanin pigment composition of blackberries. Journal of Food Science, 70(3), 198-202.

Felek, İ. (2019). Bal Kabağı ve Zivzik Nar Kabuğu Unu ile Zenginleştirilmiş Hazır Tarhana Çorbası Üretimi. Yüksek Lisans Tezi. Siirt Üniversitesi, Fen Bilimleri Enstitüsü, Siirt.

Garzon, G. A., Riedi, K. M., \& Schwartz, S. J. (2009). Determination of anthocyanins, total phenolic content, and antioxidant activity in Andes Berry (Rubus glaucus Benth). Journal of Food Science, 74(3), 227-232.

Giovanelli, G., \& Buratti, S. (2009). Comparison of polyphenolic composition and antioxidant activity of wild Italian blueberries and some cultivated varieties. Food Chemistry, 112, 903-908.

Göçmen, D., Gürbüz, O., \& Şahin, İ. (2003). Hazır tarhana çorbaları üzerinde bir araştırma. Glda, 28, 13-18.

Gökmen, S., \& Çağlar, A. (2016). Çiğ Pişmiş ve Kurutulmuş Ayva Katkısının Tarhana Üzerine Etkisi. mcol (Ed.). Saarbrücken, Deutschland: LAP LAMBERT Academic Publishing.

Grygiel-Górniak, B. (2014). Peroxisome proliferator-activated receptors and their ligands: nutritional and clinical implications-a review. Nutrition Journal, 13(1), 17.

Gülcin, I., Topal, F., Cakmakcı, R., Bilsel, M., Gören, A. C., \& Erdogan, U. (2011). Pomological features, nutritional quality, polyphenol content analysis, and antioxidant properties of domesticated and 3 wild ecotype forms of raspberries (Rubus idaeus L.). Journal of Food Science, 76(4), 585-593.

Head, K. (2001). Natural therapies for ocular disorders part two: cataracts and glaucoma. Alternative Medicine Review, 6(2), 141-141.

Huang, H. P., Chang, Y. C., Wu, C. H., Hung, C. N., \& Wang, C. J. (2011). Anthocyanin-rich Mulberry extract inhibit the gastric cancer cell growth in vitro and xenograft mice by inducing signals of p38/p53 and c-jun. Food Chemistry, 129(4), 1703-1709.

Hummer, K. E., (2010). Rubus pharmacology: antiquity to the present. Hort Science, 45(11), 1587-1591.

Huttunen, S., Toivanen, M., Arkko, S., Ruponen, M., \& TikkanenKaukanen, C. (2011). Inhibition activity of wild berry juice fractions against Streptococcus pneumoniae binding to human bronchial cells. Phytotherapy Research, 25(1), 122127.

Ibanoglu, S., \& Ibanoglu, E. (1999). Rheological properties of cooked tarhana, a cereal-based soup. Food Research International, 32, 29-33.

Ibanoglu, S., Ibanoglu, E., \& Ainsworth, P. (1999). Effect of different ingredients on the fermentation activity in Tarhana. Food Chemistry, 64, 103-106.

Iglesia, R., Milagro, F. I., Campion, J., Boque, N., \& Martinez, J. A. (2010). Healthy properties of proanthocyanidins. BioFactors, 36(3), 159-168.

Jiménez, S., Gascón, S., Luquin, A., Laguna, M., AncinAzpilicueta, C., \& Rodríguez-Yoldi, M. J. (2016). Rosa canina extracts have antiproliferative and antioxidant effects on caco-2 human colon cancer. PloS one, 11(7), e0159136. 
Kıyak, S. N. (2020). Çitlembik (Celtis australis L.) İlave Edilerek Üretilmiş Tarhananın Kimyasal ve Mikrobiyolojik Özelliklerinin İncelenmesi ve Gediz Tarhanası ile Karşılaştırılması. Yüksek Lisans Tezi. Kütahya Dumlupınar Üniversitesi, Fen Bilimleri Enstitüsü, Kütahya.

Koponen, J. M., Happonen, A. M., Mattila, P. H., \& Törrönen, A. R. (2007). Contents of anthocyanins and ellagitannins in selected foods consumed in Finland. Journal of Agricultural and Food Chemistry, 55, 1612-1619.

Krauze-Baranowska, M., Głód, D., Kula, M., Majdan, M., Hałasa, R., Matkowski, A., \& Kawiak, A. (2014). Chemical composition and biological activity of Rubus idaeus shootsa traditional herbal remedy of Eastern Europe. BMC Complementary and Alternative Medicine, 14(1), 480.

Leahy, M., Speroni, J., \& Starr, M. (2002). Latest developments in cranberry health research. Pharmaceutical Biology, 40, 5054.

Magala, M., Kohajdova, Z., Karovicova, J., \& Subova A. (2015). Utilization of citrus crops processing by-products in the prepatation of tarhana. Potravinarstvo Scientific Journal for Food Industry, 9(1), 95-100.

Mazimba, O., Majinda, R. R. T., \& Motlhanka, D. (2011). Antioxidant and antibacterial constituents from Morus nigra. African Journal of Pharmacy and Pharmacology, 5(6), 751754.

Meral, R., \& Doğan, İ. S. (2012). Karadut (Morus nigra) katkılı ekmeğin antioksidan aktivitesi ve fenolik kompozisyonu. Iğdır Üniversitesi Fen Bilimleri Enstitüsü Dergisi, 2(4), 4348.

Mihailović, N. R., Mihailović, V. B., Ćirić, A. R., Srećković, N. Z., Cvijović, M. R., \& Joksović, L. G. (2019). Analysis of wild raspberries (Rubus idaeus L.): Optimization of the ultrasonic-assisted extraction of phenolics and a new insight in phenolics bioaccessibility. Plant Foods for Human Nutrition, 74(3), 399-404.

Mullen, W., McGinn, J., Lean, M. E. J., Maclean, M. R., Gardner, P., \& Duthie, G. G. (2002). Ellagitannins, flavonoids, and other phenolics in red raspberries and their contribution to antioxidant capacity and vasorelaxation properties. Journal of Agricultural and Food Chemistry, 50, 5191-5196.

Ninomiya, K., Matsuda, H., Kubo, M., Morikawa, T., Nishida, N., \& Yoshikawa, M. (2007). Potent anti-obese principle from Rosa canina: structural requirements and mode of action of trans-tiliroside. Bioorganic \& Medicinal Chemistry Letters, 17(11), 3059-3064.

Nishizawa, T., \& Suzuki, H. (2015). Gastric carcinogenesis and underlying molecular mechanisms: Helicobacter pylori and novel targeted therapy. BioMed Research International, Article ID 794378.

Nowak, A., Sójka, M., Klewicka, E., Lipińska, L., Klewicki, R., \& Kołodziejczyk, K. (2017). Ellagitannins from Rubus idaeus L. exert geno-and cytotoxic effects against human colon adenocarcinoma cell line Caco-2. Journal of Agricultural and Food Chemistry, 65(14), 2947-2955.

Ozawa, Y., Kawashima, M., Inoue, S., Inagaki, E., Suzuki, A., Ooe, E., ... \& Tsubota, K. (2015). Bilberry extract supplementation for preventing eye fatigue in video display terminal workers. The Journal of Nutrition, Health \& Aging, 19(5), 548-554.

Öz, M., Baltacı, C., \& Deniz, İ. (2018). Gümüşhane yöresi kuşburnu (Rosa canina L.) ve siyah kuşburnu (Rosa pimpinellifolia L.) meyvelerinin C vitamini ve şeker analizleri. Gümüşhane Üniversitesi Fen Bilimleri Enstitüsü Dergisi, 8(2), 284-292.

Özarda, Ö. (2009). Üzümsü Meyvelerde Elde Edilen Ekstraktların Antioksidan Aktivitelerinin Belirlenmesi ve Meyveli İçeceklerdeki Raf Ömrüne Etkisi. Yüksek Lisans Tezi. Gebze Teknik Üniversitesi, Gebze Yüksek Teknoloji Enstitüsü, Kocaeli.

Özçelik, A. Ö., \& Özdoğan, Y. (2007). Tarhananın Türk beslenme kültüründeki yeri ve önemi. 38. Icanas Uluslararası Asya ve Kuzey Afrika Çalışmaları Kongresi (ss. 1025-1040). Ankara, 10-15 Eylül 2007.

Özgen, M., Serçe, S., \& Kaya, C. (2009). Phytochemical and antioxidant properties of anthocyanin-rich Morus nigra and Morus rubra fruits. Scientia Horticulturae, 119(3), 275-279.

Pehluvan, M., \& Güleryüz, M. (2004). Ahududu ve bögürtlenlerin insan sağlığı açısından önemi. Bahçe, 33(1), 51-57.

Pires, T. C., Caleja, C., Santos-Buelga, C., Barros, L., \& Ferreira, I. C. (2020). Vaccinium myrtillus L. fruits as a novel source of phenolic compounds with health benefits and industrial applications-a review. Current Pharmaceutical Design, 26(16), 1917-1928.

Puupponen-Pimiä, R., Nohynek, L., Ammann, S., OksmanCaldentey, K. M., \& Buchert, J. (2008). Enzyme-assisted processing increases antimicrobial and antioxidant activity of bilberry. Journal of Agricultural and Food Chemistry, 56(3), 681-688.

Qin, Y., Xia, M., Ma, J., Hao, Y., Liu, J., Mou, H., ... \& Ling, W. (2009). Anthocyanin supplementation improves serum LDLand HDL-cholesterol concentrations associated with the inhibition of cholesteryl ester transfer protein in dyslipidemic subjects. The American Journal of Clinical Nutrition, 90(3), 485-492.

Riva, A., Togni, S., Franceschi, F., Kawada, S., Inaba, Y., Eggenhoffner, R., \& Giacomelli, L. (2017). The effect of a natural, standardized bilberry extract (Mirtoselect $\AA$ ) in dry eye: a randomized, double blinded, placebo-controlled trial. European Review for Medical and Pharmacological Sciences, 21(10), 2518-2525.

Ruel, G., Pomerleau, S., Couture, P., Lemieux, S., Lamarche, B., \& Couillard, C. (2008). Low-Calorie cranberry juice supplementation reduces plasma oxidized LDL and cell adhesion molecule concentrations in men. British Journal of Nutrition, 99(2), 352-359.

Sangiovanni, E., Vrhovsek, U., Rossoni, G., Colombo, E., Brunelli, C., Brembati, L., ... \& Dell'Agli, M. (2013). Ellagitannins from Rubus berries for the control of gastric inflammation: in vitro and in vivo studies. PloS one, 8(8), e71762.

Sarıburun, E. (2009). Bursa'da Yetiştirilen Bazı Ahududu (Rubus idaeus L.) ve Bögürtlen (Rubus fruticosus L.) Çeşitlerinin Fenolik Bileşiklerinin Sıv1 Kromatografisi Kütle Spektrometresi (LC-MS) ile İncelenmesi ve Antioksidan 
Aktivite Tayinleri. Yüksek Lisans Tezi. Uludağ Üniversitesi, Fen Bilimleri Enstitüsü, Bursa.

Savikin, K., Zdunic, G., Jankovic, T., Tasic, S., Menkovic, N., Stevic, T., \& Dordevic, B. (2009). Phenolic content and radical scavenging capacity of berries and related jams from certificated area in Serbia. Plant Foods for Human Nutrition, 64, 212-217.

Savikin, K., Zdunic, G., Jankovic, T., Godevac, D. Stanojkovic, T., \& Pljevljakusic, D. (2014) Berry fruit teas: Phenolic composition and cytotoxic activity. Food Research International, 62, 677-683.

Schuster, B., \& Herrmann, K. (1985). Hydroxybenzoic and hydroxycinnamic acid derivatives in soft fruits. Phytochemistry, 24(11), 2761-2764.

Scibisz, I., \& Mitek, M. (2009). Effect processing storage conditions on phenolic compounds and antioxidant capacity of highbush blueberry jams. Polish Journal of Food and Nutrition Sciences, 59(1), 45-52.

Settanni, L., Tanguler, H., Moschetti, S. R., Gargano, V., \& Erten, H. (2011). Evolution of fermenting microbiota in tarhana produced under controlled technological conditions. Food Microbiology, 28, 1367-1373.

Sezer, E. D., Oktay, L. M., Karadadaş, E., Memmedov, H., Selvi Gunel, N., \& Sözmen, E. (2019). Assessing anticancer potential of blueberry flavonoids, quercetin, kaempferol, and gentisic acid, through oxidative stress and apoptosis parameters on HCT-116 cells. Journal of Medicinal Food, 22(11), 1118-1126.

Siriwoharn, T., \& Wrolstad, R. E. (2004). Polyphenolic composition of marion and evergreen blackberries. Journal of Food Science, 69(4), 233-240.

Siriwoharn, T., Wrolstad, R. E., Finn, C. E., \& Pereira, C. B. (2004). Influence of cultivar, maturity, and sampling on blackberry (Rubus L. Hybrids) anthocyanins, polyphenolics, and antioxidant properties. Journal of Agricultural and Food Chemistry, 52(26), 8021-8030.

Stoner, G. D., Chen, T., Kresty, L. A., Aziz, R. M., Reinemann, T. \& Nines, R. (2006). Protection against esophageal cancer in rodents with iyophilized berries: potential mechanisms. Nutrition and Cancer, 54(1), 33-46.

Sun, J., Chu, Y. F., Wu, X. Z., \& Liu, R. H. (2002). Antioxidant and antiproliferative activities of common fruits. Journal of Agricultural and Food Chemistry, 50, 7449-7454.

Şemşimoğlu, E. (2019). Çeşitli Üzümsü Meyvelerin İlavesi ile Tarhana Üretimi Üzerine Bir Araştırma. Yüksek Lisans Tezi. Afyon Kocatepe Üniversitesi, Fen Bilimleri Enstitüsü, Afyonkarahisar.

Tahir, L., Aslam, A., \& Ahmed, S. (2017). Antibacterial activities of Diospyros blancoi, Phoenix dactylifera and Morus nigra against dental caries causing pathogens: An in vitro study. Pakistan Journal of Pharmaceutical Sciences, 30(1), 163-169.

Toivanen, M., Huttunen, S., Lapinjoki, S., \& Tikkanen-Kaukanen, C. (2011). Inhibition of adhesion of Neisseria meningitidis to human epithelial cells by berry juice polyphenolic fractions. Phytotherapy Research, 25(6), 828-832.
Tomar, O., Çağlar, A., \& Akarca, G. (2020). Quality characteristics of tarhana produced with different ratios of whole wheat and buckwheat flour. Gida, 45(3), 421-432.

Vu, K. D., Carlettini, H., Bouvet, J., Cote, J., Doyon, G., \& Sylvain, J. F. (2012). Effect of different cranberry extracts and juices during cranberry juice processing on the antiproliferative activity against two colon cancer cell lines. Food Chemistry, 132(2), 959-967.

Vvedenskaya, I. O., Rosen, R. T., Guido, J. E., Russell, D. J., Mills, K. A., \& Vorsa, N. (2004) Characterization of flavonols in cranberry (Vaccinium macropon) powder. Journal of Agricultural and Food Chemistry, 52, 188-195.

Wilson, J. A., Bose, P., Proch, J., Al Kharrat, H., \& Samman, N. (2008). Cranberries and cranberry products: Powerful in vitro, ex vivo, and in vivo sources of antioxidants. Journal of Agricultural and Food Chemistry, 56(14), 5884-5889.

Xu, J., Jönsson, T., Plaza, M., Håkansson, Å., Antonsson, M., Ahrén, I. L., ... \& Granfeldt, Y. (2018). Probiotic fruit beverages with different polyphenol profiles attenuated early insulin response. Nutrition Journal, 17(1), 34.

Yalg1-Uygur, E. (2015). Karadut (Morus nigra) Meyvesinin Baz1 Fiziksel ve Kimyasal Özelliklerinin Belirlenmesi. Yüksek Lisans Tezi. Afyon Kocatepe Üniversitesi, Fen Bilimleri Enstitüsü, Afyonkarahisar.

Yi, O., Jovel, E. M., Towers, G. H. N., Wahbe, T. R., \& Cho, D. (2007). Antioxidant and antimicrobial activities of native Rosa sp. from British Columbia, Canada. International Journal of Food Sciences and Nutrition, 58, 178-189.

Zhang, L., Ma, J., Pan, K., Go, V. L., Chen, J., \& You, W. C. (2005). Efficacy of cranberry juice on Helicobacter Pylori infection: A double-blind, randomized placebocontrolled trial. Helicobacter, 10(2), 139-145.

Zia-Ul-Haq, M., Riaz, M., De Feo, V., Jaafar, H. Z. E., \& Moga, M. (2014). Rubus Fruticosus L.: Constituents, biological activities and health related uses. Molecules, 19(8), 1099811029 . 